\title{
Determinants of adaptation to climate variability among farming households in Tyhume Valley communities, Eastern Cape province, South Africa
}

Adaptation to climate variability

Olona Mtintsilana and Babatope Ebenezer Akinyemi Department of Agricultural Economics and Extension, University of Fort Hare, Alice, South Africa, and

Leocadia Zhou

Risk and Vulnerability Research Science Centre, University of Fort Hare, Alice, South Africa

\begin{abstract}
Purpose - This paper aims to determine factors affecting adaptation to climate variability on crop production among farming households in Tyhume Valley.

Design/methodology/approach - This study conducted an empirical analysis of the impact of adaptation on crop yield of farming households and estimated the factors affecting adaptation to climate variability on farming households. The analysis used primary data from 205 farming households practicing crop production in Tyhume Valley communities.

Findings - Based on binary logit results, factors affecting rural farming households' adaptation to climate variability are gender, age, heatwave, employment status, strong high wind occasional experience and cell phone. The adaptation measures adopted by the farming households in the study area include irrigation $(94.8 \%)$, crop rotation (66\%), changing crop variety $(7.4 \%)$ and other methods of adaptation were found to be $(1.3 \%)$. The other methods of adaptation used included the use of ash to kill (intuku) mole and using dirty water from washing dishes and clothes when irrigating to kill parasites on crops.

Originality/value - This research paper will be an addition to the body of knowledge on adaptation strategies to climate variability in South Africa, especially at the rural farming household level. This study may assist the rural communities in decision-making when dealing with the challenges of climate variability on their crop production, thereby increasing their crop production. The information gathered in this study might assist policymakers in revising the existing policies. This study will also help rural farming households to practice appropriate adaptation strategies.
\end{abstract}

Keywords Climate variability, Adaptation strategies and farming households, Adaptation strategy, Household farmer

Paper type Research paper

(C) Olona Mtintsilana, Babatope Ebenezer Akinyemi and Leocadia Zhou. Published by Emerald Publishing Limited. This article is published under the Creative Commons Attribution (CC BY 4.0) licence. Anyone may reproduce, distribute, translate and create derivative works of this article (for both commercial and non-commercial purposes), subject to full attribution to the original publication and authors. The full terms of this licence may be seen at http://creativecommons.org/licences/by/4.0/ legalcode

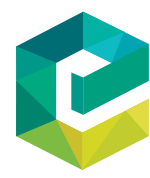

Received 16 June 2020 Revised 20 October 2020

18 November 2020 12 January 2021

Accepted 25 January 2021 
IJCCSM

13,2

\section{Introduction}

Intergovernmental Panel on Climate Change (2018) defines climate variability as the variations in the mean state and other statistics (such as standard deviations, statistics of extremes and so on) of the climate on all temporal and spatial scales beyond that of individual weather events. Climate variability is one of the biggest challenges the world is facing, and it has become one of the main fears to many farming households because of the unpleasant effects it has on agricultural productivity, therefore adapting to climate variability is of utmost importance.

Adaptation to climate variability is a primary approach to manage the future of climatic risks (Fankhauser, 2016). Bandyopadhyay et al. (2011) note that adaptation in agriculture is recognized as a critical component for reducing adverse climatic impacts. The IPCC (2018) defines adaptive capacity as the ability of a system to adjust to climate change (including climate variability and extremes), to moderate potential damages, to take advantage of opportunities or to cope with the consequences. The purpose of adaptation measures should be to increase the capacity of an organization to survive external shocks or change. The assessment of farming household's adoption of adaptation strategies is important to provide information that can be used to formulate policies that enhance adaptation as a tool for managing a variety of risks associated with climate change in agriculture (International Food Policy Research Institute, 2007).

Shuaibu et al. (2014) define adaptation strategies as the techniques used by a region or a sector to respond to changes in their livelihood through either autonomous or planned adaptation. Farming households have developed a number of strategies to live with climate variability and uncertainty such as shifting planting dates, using drought-tolerant crops and transplanting. Shuaibu et al. (2014) argue that actions taken by households against climate variability constantly change with different situations; most households use a combination of responses to the impact of climate on their livelihoods. In general, the farming households do not follow a single adaptive strategy; different strategies are taken to maximize households' positive survival. However, farming households respond to climate variability effects, as use of adaptation strategies are influenced by their socioeconomic factors (González-Hernández et al., 2019).

Ziervogel et al. (2014) opine that various studies on adaptation to climate have been carried out in South Africa. However, there exists very little focus on adaptation strategies to climate variability at farming household level. Lack of information concerning climate variability forecasting and information concerning adaptation options and other agricultural activities, rationing inputs and lack of seed inputs are some of the important constrains for farming household to adapt to climate variability. Lack of credit and household income also limit the ability of the farmers to get necessary resources and technologies needed to adapt to climate variability [International Food Policy Research Institute (IFPRI), 2007].

Scarcity of available water (both irrigation and drinking) is one of the most severe problem of the farming households in terms of adoption of climate variability adaptation strategies. Increasing size of a farming household operation decreases the probability of adopting adaptive strategies to climate variability. Adaptation measures are important in helping the poor communities to cope with extreme weather conditions associated with climate variability. Without measures at the local level to adapt to climate variability, risk of food insecurity will increase. Therefore, there is a need to explore adaptation strategies and factors that affect the decision of adopting adaptation strategies within Tyhume Valley in the Eastern Cape Province. 
Bringing more insights into factors affecting adaptation to climate variability, the objective of this research sought to determine factors affecting adaptation to climate variability among farming households. In that endeavor, the most potent question then would be what are the factors that affect the decision of farming households to adopt climate variability adaptation strategies in Tyhume Valley?

Binomial logit model is the econometric approach the author used to determine factors affecting adaptation to climate variability.

\section{Materials and methods}

\subsection{Description of the study area}

The study was carried out in Tyhume Valley, which is found in Alice under Raymond Mhlaba Local Municipality, formerly known as Nkonkobe Local Municipality within the Eastern Cape Province of South Africa (Figure 1).

Just a few kilometers before reaching Alice is the turnoff for the Hogsback road that goes up the heart of the Tyhume Valley. Tyhume Valley has high potential for agricultural production; approximately $60 \%$ of the land within Tyhume Valley can be used for agricultural purposes. The average annual rainfall and temperature for Tyhume Valley are $386 \mathrm{~mm}$ of rain per year and $29^{\circ} \mathrm{C}$, respectively. Raymond municipality has a population size of 127,115 , with most people being black.

\subsection{Research methodology}

The study used a cross-sectional survey of farming households. The data collection instruments used were semi-structured questionnaire. This data pertained to socioeconomic characteristics, demographics, factors affecting the adoption of adaption strategies in farming households and adaptation strategies used by farming households to counteract the severity of climate variability on crop production. The targeted population was the farming households of Tyhume Valley. A total of 205 household farmers were selected from the

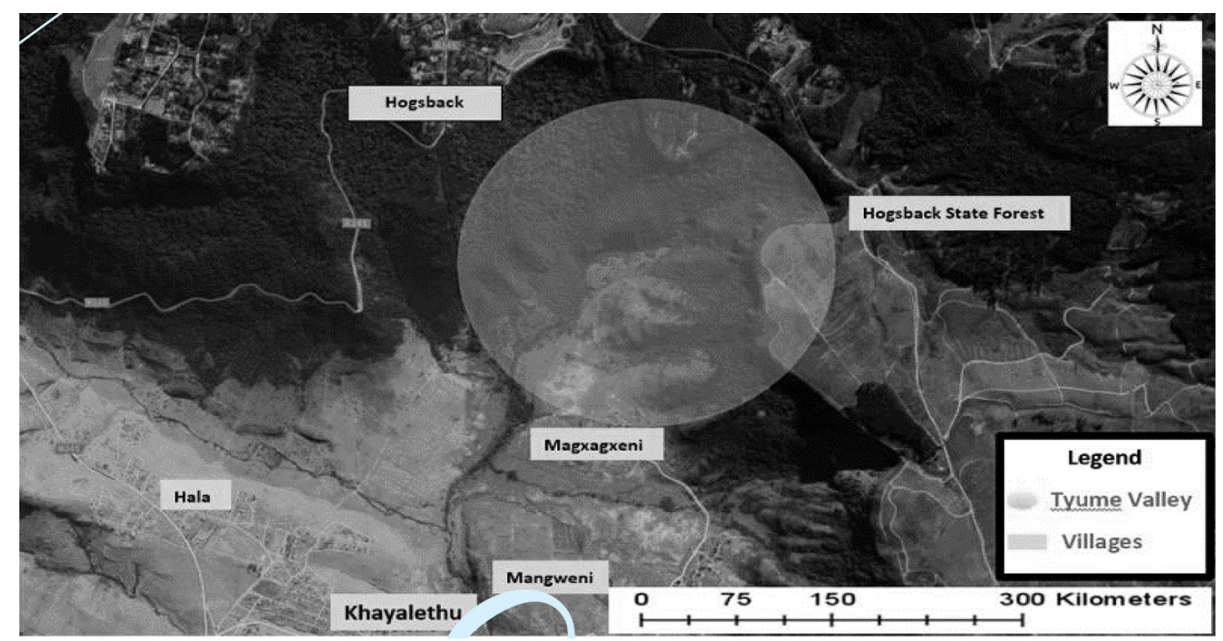

Source: Mtintsilana et al. (2020)
Adaptation to climate variability 
IJCCSM

13,2

184

study area based on they were crop farmers. The sampling technique used was purposive in determining the respondents who participated in the study.

\subsection{Analytical framework}

The study used the binary logistic regression as used by Fadina and Barjolle (2018), and Abid et al. (2015), to estimate farmers' adaptation strategies and their determinants to climate change. For this analysis, the data were run using statistical software (STATA). Binary logistic regression is a type of regression analysis where the dependent variable is a dummy variable (coded 0, 1). According to Greene (2003), the logit model takes the following form:

$$
P I=\beta 0+\beta 1 X 1+\beta 2 X 2+\beta 3 X 3+\ldots \beta n+\mu i
$$

where $\beta 0=$ intercept term;

$\beta 1, \beta 2, \beta 3 \ldots \beta n=$ slope of the parameters or regression coefficients of the model which measures a unit change in explanatory variables;

$X 1, X 2 \ldots=$ Explanatory or independent variables or factors that explain the adaptability of farming household to climate variability; and

$\varepsilon=$ error or disturbance term.

The dependent variable (adaptation status) was determined by assigning a value of 1 for household farmers who indicated that they had taken adaptive measures in response to negative effects of climate variability. A value of 0 was assigned for household farmers who indicated that they did not engage in any adaptive measures at all in response to negative effects of climate variability. For instance, if a farming household uses at least one coping strategy to abate the negative consequences of climate variability, then that farming household is considered to have "adapted" (1).

\subsection{Econometrics terms used explained}

Marginal effects: The marginal effects are nonlinear functions of the parameter estimates and the levels of the explanatory variables, ME measure discrete change, i.e. how do predicted probabilities change as the binary independent variable changes from 0 to 1 .

Variance inflation factor (VIF): The VIF factor quantifies the extent of correlation between one predictor and the other predictors in a model. It is used for diagnosing collinearity/multicollinearity.

Standard error: A measure of the statistical accuracy of an estimate, equal to the standard deviation of the theoretical distribution of a large population of such estimates.

Likelihood ratio: Likelihood ratios are ratios of probabilities and alternative statistics for summarizing diagnostic accuracy and can be treated in the same way as risk ratios for the purposes of calculating confidence intervals (Table 1).

\section{Results and discussion}

\subsection{Adaptation strategies adopted by farming households' heads}

In response to climate variability, the farming households in the study area have undertaken a number of adaptation measures to counteract the severity of climate variability on crop production. The adaptation measures adopted by the farming households in the study area include crop rotation (66 \%), changing crop variety $(7.4 \%)$ and other methods of adaptation were found to be $(1.3 \%)$. The other methods of adaptation used included the use of ash to kill (intuku) mole and using dirty water from washing dishes and clothes when irrigating to kill parasites on crops (Figure 2). 


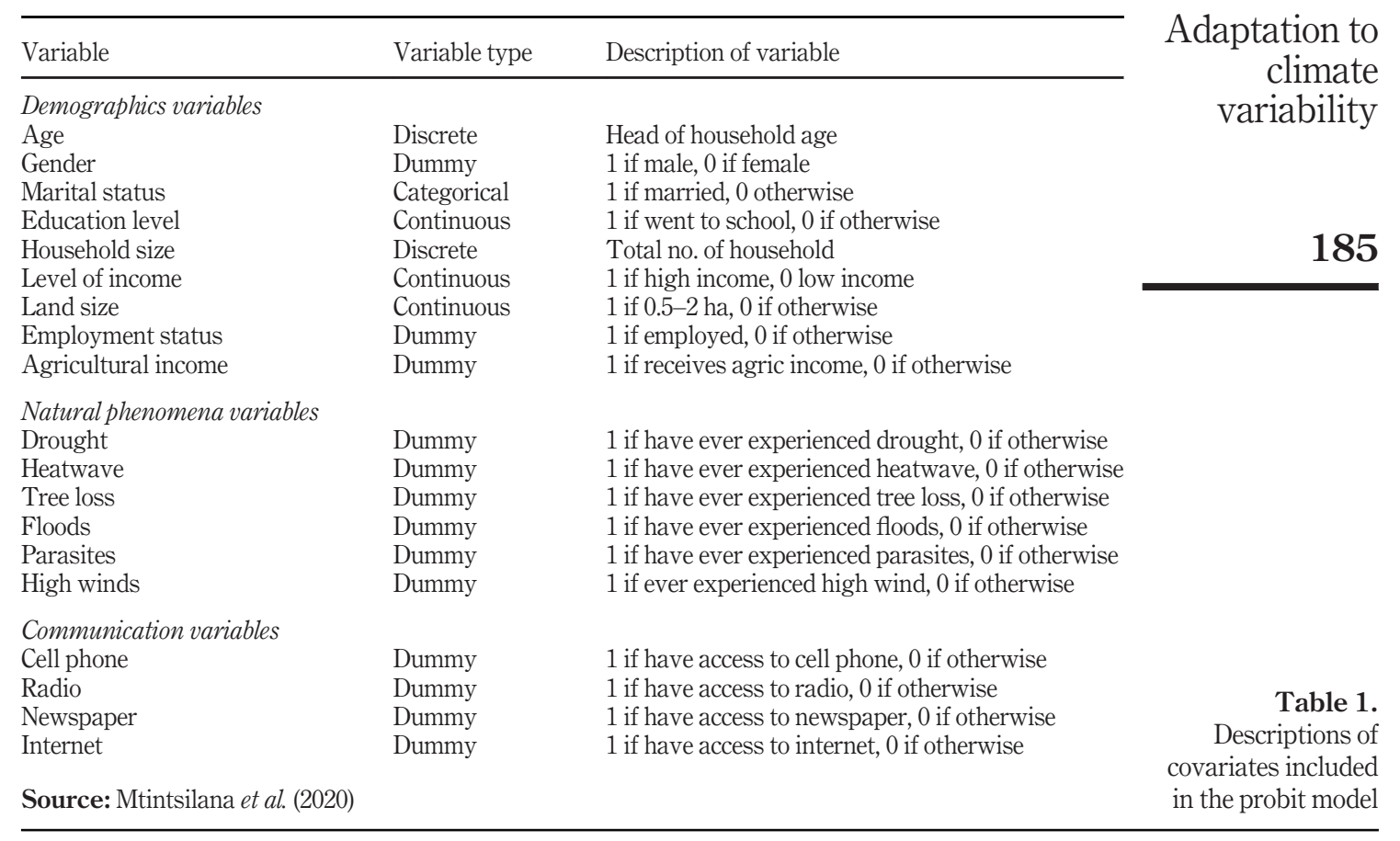

In total $94.8 \%$ of the respondents use irrigation as a coping strategy to adapt to climate variability. This may be because rainwater harvesting irrigation is easily accessible in rural settlements and is less expensive.

\subsection{Factors affecting adaptation to climate variability}

Table 2 shows that the logistic model successfully predicted that in the study area adaptation to climate variability was significant and positively influenced by employment status and cell phones at $5 \%$ and $10 \%$, respectively. Gender, age, heat wave and strong high

\section{ADOPTED ADAPTATION STRATEGIES}

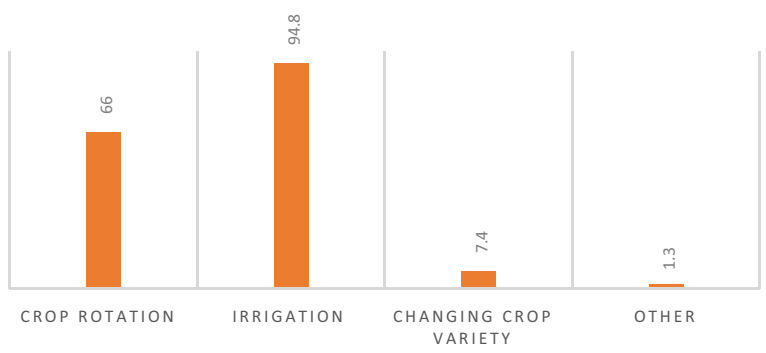

Source: Mtintsilana et al. (2020)

Figure 2.

Distribution of households' adaptation strategies 


\begin{tabular}{|c|c|c|c|c|c|}
\hline \multirow{2}{*}{$\begin{array}{l}\text { IJCCSM } \\
13,2\end{array}$} & \\
\hline & Variables & $\beta$ & ME & SE & VIF \\
\hline \multirow{6}{*}{186} & Constant & 7.8591 & & 5.5910 & \\
\hline & Gender & $-1.0824^{* * * * *}$ & -0.1632 & 0.3960 & 1.1800 \\
\hline & Age & $-0.0391^{*}$ & -0.0059 & 0.0232 & 2.2400 \\
\hline & Marital status & -0.3720 & -0.0560 & 0.4123 & 1.2900 \\
\hline & Educational level & 0.0117 & 0.0017 & 0.0761 & 2.5000 \\
\hline & Household size & -0.0946 & -0.0142 & 0.0900 & 1.3000 \\
\hline \multirow{19}{*}{$\begin{array}{l}\text { Table } 2 \text {. } \\
\text { Factors affecting } \\
\text { adaptation to climate } \\
\text { variability }\end{array}$} & Employment status & $1.2922^{*}$ & 0.1948 & 0.5844 & $\begin{array}{l}1.8300 \\
1.3700\end{array}$ \\
\hline & $\begin{array}{l}\text { Level of income } \\
\text { Land size }\end{array}$ & $\begin{array}{l}0.1266 \\
0.2763\end{array}$ & $\begin{array}{l}0.0190 \\
0.0416\end{array}$ & $\begin{array}{l}0.3010 \\
0.5071\end{array}$ & $\begin{array}{l}1.3700 \\
1.2600\end{array}$ \\
\hline & Drought & -0.6153 & -0.0927 & 0.4787 & 1.0900 \\
\hline & Heatwave & $-0.2648^{* *}$ & -0.3414 & 1.0741 & 1.1300 \\
\hline & Tree loss & 0.5666 & 0.0854 & 1.7436 & 1.1900 \\
\hline & Floods & -0.2528 & -0.0381 & 1.7692 & 1.1900 \\
\hline & Parasites & 0.1372 & 0.0207 & 0.6052 & 1.0700 \\
\hline & Strong high wind & $-1.1457^{* * *}$ & -0.1727 & 0.5384 & 1.3200 \\
\hline & Agricultural income & 0.7214 & 0.1087 & 1.3719 & 1.0400 \\
\hline & Internet & -0.8728 & -0.1316 & 1.4229 & 1.1800 \\
\hline & Radio & -0.9420 & -0.1420 & 0.8081 & 1.1600 \\
\hline & Cell phone & $0.9676^{*}$ & -0.1458 & 0.5433 & 1.1700 \\
\hline & Newspaper & -0.8934 & -0.1347 & 1.0849 & 1.3200 \\
\hline & $\begin{array}{l}\text { Mean VIF } \\
N=205\end{array}$ & & & & 1.3600 \\
\hline & LR chi ${ }^{2}$ & & 53.5700 & & \\
\hline & Prob $>\mathrm{chi}^{2}$ & & 0.0000 & & \\
\hline & Pseudo $R^{2}$ & & 0.2210 & & \\
\hline & Log-likelihood & & -94.3910 & & \\
\hline & \multicolumn{5}{|c|}{ Notes: $* * *$ Significant at $1 \%$ level; **Significant at $5 \%$ level; $*$ Significant at $10 \%$ level } \\
\hline
\end{tabular}

winds significantly and negatively affect farmers' ability to adapt to climate variability. Gender of the household head was significant at $1 \%$, age was significant at $10 \%$ and heat wave, and high winds were both significant at $5 \%$ level.

Model was statistically significant at $(\phi=0.01)$ level, implying that the model fit the data well with Pseudo $R^{2}$ of 0.2210 indicating a $22 \%$ variation in the dependent variable (i.e. adaptation to climate variability) explained by the explanatory variables included in the model. The marginal effects are nonlinear functions of the parameter estimates and the levels of the explanatory variables, also MEs measure discrete change, i.e. how do predicted probabilities change as the binary independent variable changes from 0 to 1 . The study used the VIF to check for multicollinearity. Table 4 shows that all variables had a low VIF that was between 1 and 2 and mean VIF 1.36 implying that there was zero multicollinearity (Maddala, 2000). Therefore, this justified the inclusion of these variables in the binary logit model analysis.

Table 2 depicts that employment status of the farming household has a positive and significant effect on adaptation to climate variability. The variable was statistically significant at $5 \%$ level with marginal effect of $19 \%$. This meant that farmers who were employed were $19 \%$ likely to adapt to climate variability than those who were not employed. The possible explanation for this finding might be that the employed farming households have more income than the unemployed farming households, and the higher the 
income the greater the chances of adapting to climate variability. Lyu et al. (2019) stated that unemployment is one of the socioeconomic issues that rural farming households have to deal with. For cell phones the variable was statistically significant at $10 \%$ level. Furthermore, regression analysis showed a positive relation between farming households who have access to cell phones and adaptation to climate variability. Therefore, farming household who have access to cell phones are more likely to adapt to climate variability than those who do not. As shown by the marginal effect where farming household with access to cell phones have $14 \%$ probability of adapting to climate variability compared to farming households

Adaptation to climate variability with no access to cell phones. Emeana et al. (2020) noted that cell phones improve farming households' ability to access information from host information providers such as seed and pesticide researchers, input dealers and agricultural extension officials from the state.

Age of the respondents was significant at $10 \%$ significant level. The coefficient was negative suggesting that adapting to climate variability increases as age decreases. Meaning younger farming households tend to adapt to climate variability more than the elderly farming household. This is in line with the findings from National Climate Change Adaptation Research Faculty (2011), which observed that elderly people's physical strength, stamina and mobility are reduced owing to their age, which then leads to them being unable to adapt to climate variability. Organisation for Economic Co-operation and Development (2016) also opined that age affects elderly people vulnerability and their capacity to respond to climate variability, even though they are concerned about climate variability, however they are not able personally to take action to stop it. The marginal effects confirm that $0.5 \%$ of younger farming households people have a probability of adapting to climate variability compared to old farming households. Age is an influencing factor in making a person more or less accepting of climate variability and their willingness to adapt as a result.

Household head gender was found to be negatively related and significant at $1 \%$. It is commonly known that climate variability does not affect people equally and that gender is a critical factor in understanding vulnerability to climate variability (Goodrich et al., 2019). Abebe and Mulu (2017) stated that home gardening is dominated and associated with women. This is in line with the descriptive statistics which indicated that majority of farming households in Tyhume Valley are headed by females (53 \%) than males (46.8\%). Therefore, it is more difficult for female farmers to adapt to climate variability compared to males as shown by the marginal effects where females have a $16 \%$ probability of adapting to climate variability compared to males; this maybe because woman face many cultural restrictions which then makes it more difficult for them to apply certain methods of adaptation.

Heatwave was significant $5 \%$ level but negatively related implying that the higher the levels of heat wave, the less willing is the farmer to adapt to climate variability. This was proven by the marginal effect probability of $34 \%$. The implication is that farmers who experience heatwave are $34 \%$ likely not to adapt to climate variability than those who do not. Heatwave is a health risk, and all people are vulnerable during a heat wave, more especially the elderly people. As shown in the demographic results, the respondents from the study area were dominated by elderly household heads, some of whom made a claim that during heatwave it is difficult for them to work on or irrigate their gardens. This claim is supported by a study done by Akompbab et al. (2013) and International Labour Office (2019), which made the findings that during heatwave most farming households do not perform outdoor gardening, as a result their crop production declined and some ended up neglecting farming.

Strong high winds have a significant impact on barriers to adaptation. The variable was statistically significant at 5\% level. The coefficient was negative suggesting that adaptation to climate variability decreases as the high winds increase. This was proven by the marginal effect probability of $17 \%$. The implication is that farmers who experience high winds are $17 \%$ likely to 
IJCCSM 13,2

188

adapt to climate variability than those who do not. Respondents pointed out that when performing sprinkler irrigation, the wind blows the water around and this is unavoidable. Strong high winds can cause deleterious damage on corn crops. The damage includes minor leaning or bending of plants and outright uprooting of plants (root lodging) (Pioneer Crop Insights, 2011). The respondents indicated that they had made investments by building infrastructure that can withstand high winds, however, that does not help them as the material used to build such infrastructure becomes a danger to them and sometimes it would fall and kill the crops.

\section{Conclusions and implications}

Findings obtained using binary logistic regression model demonstrated that only six variables: gender, age, employment status, heatwave, strong high winds and cell phone affected the adoption of adaptation strategies to climate variability for Tyhume Valley farming households. Of the six variables two (unemployment and cell phones) that positively and significantly influence adaptation toward climate variability, while gender, age, heatwave and high winds were found to be negatively and significantly influencing adaptation toward climate variability.

Coping with climate variability is an increasingly important issue in agriculture and one that is likely to persist for many years. To increase crop yield, farming households will need to adapt to climate variability. Some adaptation efforts will happen in association with farming households making the best management decisions for their operation. Adaptation measures are important in helping the poor communities to cope with extreme weather conditions associated with climate variability. Without measures at the local level to adapt to climate variability, crop production of farming households will not increase.

Given that the majority of farming households are old and are females and most adaptation strategies are labor intensive, there is a need for development of labor-saving technologies and extension services to increase the likelihood of adaptation of climate variability by vulnerable farmer such as women and elderly farmers. There is a need for the development of infrastructure for farmers as they are negatively affected by high winds owing to low infrastructural development. The improvement in infrastructure development will play crucial role in improving their agricultural productivity. The study shows that farming households who have access to cell phones are more likely to adapt to climate variability, therefore the study recommends that communication of farming households must be improved.

\section{References}

Abebe, T. and Mulu, D. (2017), "The role of women in the management and utilization of home garden: the case of dale district, in Southern Ethiopia. Pelagia research library", Asian Journal of Plant Science and Research, Vol. 7 No. 4, pp. 41-54.

Abid, M., Scheffran, J., Schneidor, V.A. and Ashfaq, M. (2015), "Farmers 'perceptions of and adaptation strategies to climate change and their determinants: the case of Punjab province, Pakistan", Copernicus Publications, pp. 225-243, doi: 10.5194/esd-6-225-2015, (accessed 16 August 2018).

Akompab, D.A., Williams, B.P., Grant, J., Walker, I.A. and Augoustinos, M. (2013), "Heat waves and climate change: applying the health belief model to identify predictors of risk perception and adaptive behaviours in Adelaide, Australia", International Journal of Water Resources Development, Vol. 10 No. 6, pp. 2164-2184, available at: http://dx.doi.org/10.1080/07900627.2016.1262246

Bandyopadhyay, S. Wang, L. and Wijnen, M. (2011), "Improving household survey instruments for understanding agricultural household adaptation to climate change: water stress and variability”, John Wiley and Sons (accessed 22 September 2017)

Emeana, E.M., Trenchard, L. and Dehnen-Schmutz, K. (2020), "The revolution of mobile phone-enabled services for agricultural development (m-Agri services) in Africa: the challenges for 
sustainability”, Sustainability, Vol. 12 No. 2, p. 485, doi: 10.3390/su12020485, available at: www. mdpi.com/journal/sustainability

Fadina, R. and Barjolle, D. (2018), "Farmers 'Adaptation strategies to climate change and their implications in the zou department of South Benin", Department of Environmental Systems Science, Vol. 5 No. 1, p. 15, doi: 10.3390/environments5010015.

Fankhauser, S. (2016), "Adaptation to climate change, annual reviews of resource economics", doi 10.1146/annurev-resource-100516-033554, available at: https://ssrn/abstract=2869292

González-Hernández, D.L., Meijles, E.W. and Vanclay, F. (2019), "Household barriers to climate change action: perspectives from Nuevo Leon, Mexico”, Sustainability, Vol. 11 No. 15, pp. 1-14, doi: 10.3390/sul1154178.

Goodrich, C.G., Udasa, P.B. and Larrington-Spencer, H. (2019), "Conceptualizing gendered vulnerability to climate change in the Hindu Kush Himalaya: contextual conditions and drivers of change", Environmental Development, Vol. 31, pp. 9-18.

Greene, W.H. (2003), Econometric Analysis, Fifth edition, Prentice Hall, New Jersey.

IFPRI (International Food Policy Research Institute) (2007), "Micro-level analysis of farmers' adaptation to climate change in Southern Africa", Ifpri. discussion paper 00714 august 2007.

ILO (International Labour Office (2019), "Working on a warmer planet, the impact of heat stress on labour productivity and decent work", Produced by the Publications Production Unit (PRODOC) of the ILO. ISBN 978-92-2-132968-8 (web pdf)

IPCC (Intergovernmental Panel on Climate Change) (2018), “Annex I: glossary”, in Matthews, J.B.R. (Ed.), Global Warming of $1.5^{\circ} \mathrm{C}$. An IPCC Special Report on the Impacts of Global Warming of $1.5^{\circ} \mathrm{C}$ above Pre-Industrial Levels and Related Global Greenhouse Gas Emission Pathways, in the Context of Strengthening the Global Response to the Threat of Climate Change, Sustainable Development, and Efforts to Eradicate Poverty, Masson-Delmotte, V., P. Zhai, H.-O. Pörtner, D. Roberts, J. Skea, P.R. Shukla, A. Pirani, W. Moufouma-Okia, C. Péan, R. Pidcock, S. Connors, J.B.R. Matthews, Y. Chen, X. Zhou, M.I. Gomis, E. Lonnoy, T. Maycock, M. Tignor, and T. Waterfield (Eds), In Press.

Lyu, H., Dong, Z., Roobavannan, M., Kandasamy, J. and Pande, S. (2019), "Rural unemployment pushes migrants to urban areas in Jiangsu province, China", PALGRAVE Communications, Vol. 5 No. 1, doi: 10.1057/s41599-019-0302-1, available at: www.nature.com/palcomms

Maddala, G.S. (2000), Introduction to Econometrics, 3rd ed., Prentice-Hall, NJ.

Pioneer Crop Insights (2011), “Crop management and corn harvesting. trademarks and service marks of pioneer Hi-Bred international”, Inc. C2010, PHII. Field facts Vol. 1 No.15. p. 2. available at: www. pioneer.com/usa/crop_management/corn/harvesting.htm

Shuaibu, H., Akpoko, J.G. and Umar, S. (2014), "Farm households' coping strategies to climate change: a review farm households ' coping strategies to climate change: a review", British Journal of Applied Science and Technology, Vol. 4 No. 20, pp. 2864-2877.

Ziervogel, G., New, M., Garderen, E.A.V., Midgley, G., Taylor, A., Hamann, R. and Stuart-Hill, S. (2014), "Climate change impacts and adaptation in South Africa", John Wiley and Sons Ltd, Vol. 5 No. October, doi: 10.1002/wcc.295

\section{Further reading}

Huynh, H.T., Hufnagel, J., Wurbs, A. and Bellingrath-Kimura, S.D. (2019), "Influences of soil tillage, irrigation and crop rotation on maize biomass yield in a 9-year field study in Müncheberg, Germany", Field Crops Research, Vol. 241, p. 107565, available at: www.sciencedirect.com/ science/article/pii/S0378429019305994 (accessed 21 November 2019).

Mangaung Metro Municipality GIS Directorate (2020), "Tyume valley map”

Mengistu, D.K. (2011), "Farmers' perception and knowledge of climate change and their coping strategies to the related hazards: case study from Adiha, Central Tigray, Ethiopia”, Agricultural Sciences, Vol. 02 No. 2, pp. 138-145, doi: 10.4236/as.2011.22020.
Adaptation to climate variability 
IJCCSM 13,2

Mubiru, D.N., Radeny, M., Kyazze, F.B., Zziwa, A., Lwasa, J., Kinyangi, J. and Mungai, C. (2018), "Climate trends, risks and coping strategies in smallholder farming systems in Uganda", Climate Risk Management, Vol. 22, pp. 4-21, available at: www.sciencedirect.com/science/article/pii/ S2212096316300821 (accessed 20 November 2019).

NCCARF (National Climate Change Adaptation Research Facility) (2011), "Ageing, the built environment and adaptation to climate change".

OECD (Organisation for Economic Co-operation and Development (2016), "Policy perspectives adapting to the impacts of climate change", OECD Publishing, Paris, available at: www.oecd. org/environment/cc/adaptation.htm

Rinkesh, K. (2018), "Advantages and disadvantages of crop rotation", Conserve Energy Future, available at: www.conserve-energy-future.com/advantages-disadvantages-crop-rotation.php

Rivera, A. Gunda, T. and Hornberger, G.M. (2017), "Minimizing irrigation water demand: an evaluation of shifting planting dates in Sri Lanka", Ambio, available at: www.ncbi.nlm.nih.gov/pmc/ articles/PMC5884765/ (accessed 21 November 2019).

Statistics South Africa (2019), "Towards Measuring the Extent of Food Security in South Africa: an examination of hunger and food inadequacy", Report no. 03-00-14, p. 34, ISBN 978-0-621-47243-1, available at: www.statssa.gov.za

Tibesigwa, B. and Visser, M. (2016), "Assessing gender inequality in food security among small-holder farm households in urban and rural South Africa”, World Development, Elsevier, Vol. 88, pp. 33-49, doi: 10.1016/j.worlddev.2016.07.008.

\section{About the authors}

Olona Mtintsilana is an Agricultural Economics Master student in the Department of Agricultural Economics and Extension, University of Fort Hare, South Africa. Olona was born and raised in the rural areas of Nqamakwe in the former Transkei. He graduated with honors in agricultural economics in the year 2016. His research interest includes rural development, climate change and food security. For his honors research project he investigated reasons why rural youth shun agriculture.

Babatope Ebenezer Akinyemi is currently working as a time-on-task lecturer in the Department of Agricultural Economics and Extension, University of Fort Hare, South Africa. He is an Agricultural and Resource Economist with special interest in Sustainable Agriculture with emphasis on rural households' food security while safeguarding environmental health. His ongoing research collaborations include Moringa Oleifera, The "Miracle Tree": Let's Bridge the Gap between Sciences and Human Consumption and Climate Change Mitigation and Adaptation Benefits of Wilder Rangelands. Babatope Ebenezer Akinyemi is the corresponding author and can be contacted at: bakinyemi@ufh.ac.za

Dr Leocadia Zhou is the Director of Risk and Vulnerability Science Centre (RVSC) (RAVAC) hosted in the Faculty of Science and Agriculture at the University of Fort Hare. With a background in geography and environmental science, Dr Zhou has an interdisciplinary research approach. Her research interests are in the broad fields of climate change, food and water security and also energy security. Dr Zhou is involved in various research projects on climate change's impact on food security. Dr Zhou has conducted research at the national, regional and international level aimed at (1) building capacity for climate change adaptation; (2) exploring the impact of climate change and vulnerability assessment; and (3) and developing policy briefs. Dr Zhou serves as a national Technical Resource Team advisor for the South Africa Vulnerability Assessment Committee (SAVAC) (RAVAC). Dr Zhou is also actively involved as a project steering committee member for the Eastern Cape Anti-Poverty Food Security Strategy in South Africa.

For instructions on how to order reprints of this article, please visit our website:

www.emeraldgrouppublishing.com/licensing/reprints.htm

Or contact us for further details: permissions@emeraldinsight.com 